\title{
บUsisersily
}

\section{Identifying nutritional myths when healthcare professionals communicate about weight and obesity in healthcare settings}

Quigley, F., Moorhead, A., Bond, RR., McAloon, T., \& Zheng, H. (2020). Identifying nutritional myths when healthcare professionals communicate about weight and obesity in healthcare settings. In Proceedings of the Nutrition Society (Vol. 79, pp. 79 (OCE3), E775). Cambridge University Press.

https://doi.org/10.1017/S0029665120007612

Link to publication record in Ulster University Research Portal

\section{Published in:}

Proceedings of the Nutrition Society

Publication Status:

Published (in print/issue): 15/07/2020

DOI:

10.1017/S0029665120007612

\section{Document Version}

Publisher's PDF, also known as Version of record

\section{General rights}

Copyright for the publications made accessible via Ulster University's Research Portal is retained by the author(s) and / or other copyright owners and it is a condition of accessing these publications that users recognise and abide by the legal requirements associated with these rights.

\section{Take down policy}

The Research Portal is Ulster University's institutional repository that provides access to Ulster's research outputs. Every effort has been made to ensure that content in the Research Portal does not infringe any person's rights, or applicable UK laws. If you discover content in the Research Portal that you believe breaches copyright or violates any law, please contact pure-support@ulster.ac.uk. 


\title{
Identifying nutritional myths when healthcare professionals communicate about weight and obesity in healthcare settings
}

\author{
F. Quigley ${ }^{1}$, A. Moorhead ${ }^{2}$, R. Bond ${ }^{3}$, T. McAloon ${ }^{1}$ and H. Zheng ${ }^{3}$ \\ ${ }^{1}$ Ulster University, Institute of Nursing and Health Research, Jordanstown, Shore Road, Newtownabbey, Co. \\ Antrim, BT37 OQB, \\ ${ }^{2}$ Ulster University, School of Communications and Media, Jordanstown, Shore Road, Newtownabbey, Co. \\ Antrim, BT37 OQB and \\ ${ }^{3}$ Ulster University, School of Computing, Jordanstown, Shore Road, Newtownabbey, Co. Antrim, BT37 OQ
}

Overweight and obesity are chronic disease risk factors, posing a significant global health challenge. ${ }^{(1)}$ Nutritional counselling is a key part of obesity prevention and treatment, but healthcare professionals receive little training in this area. ${ }^{(2)}$ In particular, disordered eating is a common presentation in patients who are living with obesity, ${ }^{(3)}$ so there is a need to recognise this when discussing nutrition, bringing in expert help, if required. The aim of this study was to explore healthcare professionals' (HCP) attitudes to raising the topic of weight with patients.

This research forms part of a 5-phase mixed-methods study to design, develop and test the feasibility of a virtual reality (VR)-based training approach to improve weight-related communication in healthcare settings. The current study addresses Phase 2 - Training Needs Analysis and has two sub-phases (1) Twitter chat with patients, researchers and HCP $(\mathrm{n}=38)$ conducted via an existing obesity chat - \#obsmuk, and (2) HCP interviews ( $\mathrm{n}=12: 4$ doctors, 6 nurses, 2 dietitians), using purposive sampling to recruit across the UK via social media. The Twitter chat was analysed using content analysis, while analysis of HCP interviews used thematic analysis.

The Twitter chat confirmed current obesity research including lack of training for HCP, lack of time for weight-related discussions, the presence of weight stigma, common misunderstandings of the role of nutrition and dissatisfaction with the standard of weight-related discussions.

From the HCP interviews, 4 themes were identified: (1) "Strategies for raising the topic of weight", (2) "Role of weight bias", (3) "HCP personal experiences with weight", and (4) "Practical strategies HCP used to engage patients". The interviews highlighted a non-standard approach to discussing weight, a lack of understanding of weight bias and a reliance on their personal weight management approaches as a source of advice.

In Theme 3 of the HCP interviews, evidence of inaccurate nutritional advice was identified, such as recommendation of diets without consideration of risk or evidence of effectiveness or appropriateness of dietary intervention, a focus on calorie reduction over and above nutritional adequacy and quality of diet, and assumptions about dietary intake.

As part of improving training for HCP to better communicate about weight and obesity, there is a need to emphasise the importance of accurate and neutral nutritional advice to dispel common myths and misunderstandings. This should include how to recognise when referral for more expert nutritional advice is needed.

1. Abdelaal M, le Roux C \& Docherty N (2017) Ann Transl Med, 5, 7, 161

2. Baute V, Sampath-Kumar R, Nelson S \& BasilGlob B (2018) Adv Health Med, 7:2164956118795995

3. Solmi F, Hatch S, Hotopf M, Treasure J \& Micali N (2014) Soc Psychiatry Psychiatr Epidemiol, 49, 8, 1335-1346 